Acta Universitatis Wratislaviensis No 3920

Anglica Wratislaviensia LVII, Wrocław 2019

DOI: $10.19195 / 0301-7966.57 .10$

\author{
Beata Mazurek-Przybylska \\ ORCID: 0000-0002-0321-7307 \\ Philological School of Higher Education, Wroclaw \\ b.mazurek_przybylska@interia.eu
}

\title{
Film Novelization as Multimodal Translation
}

\begin{abstract}
Novelization, i.e. a literary adaptation of a film, despite its widespread presence on the book market, was treated as a merely commercial phenomenon, and until the late 1990s, it did not inspire any academics research. The main objective of this paper is to show that the phenomenon of novelization can offer new opportunities for linguistics and to reconsider the place of novelization in adaptation and translation studies. It is claimed that the process of film-to-book transformation can be called a translation process. The term multimodal translation is adopted since transforming a multimodal text (film) into a monomodal one (book) involves a change of modalities and their density. What follows is an attempt to propose tools that can be used for the effective analysis of multimodal translation, which involve the classical Aristotelian view of the three-part plot of verbal texts and Elżbieta Tabakowska's theory of cognitive translation. In order to illustrate the film-book translation process, an Interstellar film segment and its book counterpart are analyzed and the conclusion has been drawn that both the film and the book units use the same orientational image schemata. These findings prove that the extension of Tabakowska's theory to multimodal texts is an adequate framework for the comparison of a film and its novelization.
\end{abstract}

Keywords: novelization, translation, multimodality, adaptation, image schemas

\section{Introduction}

Unlike filmic adaptations of literary works, which have generated wide interest among film scholars, literary adaptations of films, i.e. novelization, have been long ignored by academics. Despite its rich history and the involvement of renowned writers, it was only recently, in the late 1990s and 2000s, that there appeared works devoted to the history and phenomenon of novelization (e.g. Larsson; Van Parys "The Commercial Novelization", "The Study of Novelization"; Baetens "Expanding the Field"). It has been shown that novelization offers interesting insights not only into the development of cinema and the history of literature but also into the relationship between these two forms of art. Moreover, apart from being merely a commercial phenomenon, novelization is an example of a reverse process to 
traditional literary adaptation (book-to-film), enabling a change in perspective and the opening of new directions in filmic, literary and linguistic studies. As one of the reasons for the emergence of the phenomenon of novelization was to prolong the viewers' film experience (Murphy 26), novelization writers strive to make their books as close in content to the original films as possible. Due to this fact, the term translation seems to be more accurate to describe the relationship between a film and its novelization and in fact it has been used in this way by novelization scholars (Baetens, "Expanding the Field" 52). On the other hand, a film and a book vary in nature, since a film is by definition a multimodal phenomenon while a book is a monomodal one. To what extent then does this difference influence the view of novelization as film translation? What methodology can be employed to analyze the gains and losses which happen during the translation process? Some of the answers to these and related questions are given in this paper.

\section{Novelization}

Novelization, which has accompanied film since the origins of cinematography (see also Larsson), served different purposes, from being a marketing product ensuring higher incomes for film producers to being the only way for film fans to extend their film experience before the advent of home video. Novelizations are such an abundant form of literature that categorization of tie-in books is not an easy task. Randall Larsson (3), the first scholar to devote his academic interest to novelizations, enumerated 3 types of such books: (i) republishing of the original book that was adapted for a film, (ii) a book based on a film and (iii) a book inspired by a film using its characters and setting but original in terms of the plot. Of course, novelizations can be classified on the basis of other criteria such as the age of the readers, the format of the book (a photo novel or just a novel) or the type of source text since it is not only films that can be novelized (Van Parys "The Study of Novelization"). In the early 2000s, Belgian scholars Thomas Van Parys and Jan Baetens contributed to the emergence and development of novelization studies, as they tried to impose some order on the history of novelization. Yet linguistic studies of novelization are still virtually non-existent. It is the aim of the present paper and of the author's Ph.D. dissertation to contribute to the field and to fill, to a certain extent, this gap.

\section{Novelization and adaptation}

An important point of academic interest in tie-in book studies is the relationship between novelization and adaptation. Since in the case of novelization the original work of art is a film and the secondary product is a book, novelizations are 
often referred to as reverse adaptations or anti-adaptations (Baetens, "Novelization" 45). On the other hand, if the term adaptation is broadened to include all kinds of transformed works, then novelization can be treated as one of the types of adaptation (see Newell). Both adaptation and novelization share two problems with their reception. The first one is the lower status of both filmic adaptations and novelizations when compared to the books and the films they are based on, respectively. The reasons for the critical attitude towards both of them have been discussed in detail (see for example Stam 238, Murphy 24). The other aspect is the question of fidelity, which was the main criterion for assessing the quality of filmic adaptations in the early stage of adaptation studies. Only later did film critics and film recipients accept that due to it being a completely different medium, film cannot reflect all aspects of a literary work (Cardwell; Cahir). This results in the necessity of filmmakers having a creative attitude to the literary material being adapted, which leads to the perception of filmic adaptations as independent works of art.

This artistic and creative side is definitely less important when it comes to novelization. Being purely commercial in nature, tie-in books were invented to either extend the viewers' filmic experience or to attract potential viewers of a film. Both aims are best achieved by maintaining maximum fidelity of the book to its film. In order to comply with this rule, novelizations are frequently based on film scripts and enriched with descriptive parts, which are meant to compensate for the lack of the visual mode which is lost in the process of novelization. Novelization is therefore a type of adaptation, but the strong requirement that its content is faithful to the original film distinguishes it from other types of adaptation and enables one to also approach it as an example translation.

\section{Adaptation, novelization and translation}

As filmic adaptations have always generated a lot of academic interest and controversy, researchers resort to various analogies which enable them to gain further insight into adaptation, such as the paraphrase analogy or the translation analogy (Hutcheon 9). The latter term was inspired by Roman Jakobson's article "On Linguistic Aspects of Translation" in which the division of types of translation processes broadened the scope of interest of translation studies. In his paper, Jakobson categorized translation into intralinguistic translation, which takes place within the same language and includes all kinds of paraphrase; interlinguistic translation, which involves transposition of a text from one language into another and which represents the common understanding of the word translation; and intersemiotic translation, which occurs when a text is transposed from one semiotic system into another. Even though Jakobson did not elaborate upon his concept of intersemiotic translation, his idea of including this kind of text transformation proved fruitful 
academically. The notion of intersemiotic translation was undertaken by different groups of academics: semioticians (Eco; Dusi), linguists (Tomaszkiewicz), language teachers (Polakowski) and film researchers (Hopfinger; Hendrykowski), to mention just some of them. Despite the obvious dominance of language and verbal texts in Jakobson's typology, intersemiotic translation was welcomed by scholars as it enabled the inclusion of various semiotic systems into the phenomenon of translation.

Recently, a new path of research was indicated by the translator Henri Gottlieb, who devoted much of his attention to audiovisual translation, especially translation of films. Gottlieb (3) proposed the concept of multidimensional translation, which endeavors to encompass and categorize all possible text types and translation types from the point of view of semiotics. Gottlieb considered four main aspects which should be taken into account when creating a taxonomy of translation. The first aspect is the identity of the semiotic systems in which source texts and target texts are created, which allows one to distinguish intersemiotic and intrasemiotic types of translation. The second aspect is the number of what Gottlieb calls semiotic channels used in the texts. Depending on the change in the number of these channels, translation can be isosemiotic, diasemiotic, supersemiotic and polysemiotic. Additionally, translations can be inspirational or conventional depending on the degree of faithfulness to the source texts. The last parameter is the presence or absence of verbal elements in the source and target texts. The combinations of these aspects allow for a detailed taxonomy of translations in which a filmic version of a novel is categorized as an intersemiotic, inspirational, supersemiotic and deverbalizing type of translation (Gottlieb 7). It is also suggested that, in terms of Gottlieb's taxonomic criteria, novelizations should be viewed as intersemiotic translations and, in contrast to film adaptations, rather conventional, hyposemiotic and verbalizing. As it can be seen, there is solid ground for treating both adaptations and novelizations as translation phenomena.

For the various types of translation, traditional film adaptations and film novelizations included, Gottlieb proposed the name multidimensional translation. The dimensions denoted by the modifier multidimensional are the criteria presented and illustrated above. For the purposes of her Ph.D. research on film novelization, the present author has adopted a more adequate label of multimodal translation. There were two reasons for making this decision. Firstly, a film and a book differ with respect to the number of the so-called modalities used to construct them. Secondly, selected methods of Multimodal Analysis (Kress and Van Leeuwen; Bateman and Schmidt; Bateman) have been adopted and they have proven useful in the author's research on novelization as translation. 


\section{Film as text}

The common concept of translation assumes the existence of two texts, one of which is the source text and the other is the target text. The development of linguistics allowed for the inclusion of varied communicative units into the category of text, extending it far beyond a sole piece of writing (e.g. Halliday and Hassan). One of the most recent works on filmic texts is the publication of Janina Wildfeuer and John A. Bateman in which the authors propose their own definition of film text:

we propose a concrete definition of film as multimodal text (emphasis mine) which is meaningfully structured by a variety of semiotic modes. It is a dynamic but formally confined artifact in chronological, linear order. It may have intertextual references to further text types and may produce various communicative intentions according to the context. (10)

As Wildfeuer and Bateman state, their definition and the definition of a traditional verbal text stress the same idea: a text must be a semantic unit, the difference is in the type of semiotic resources employed, which in case of a film are also non-verbal (Wildfeuer and Bateman 124). Yet of course, being a semantic unit is not the sole textual feature of film. As Wildfeuer (1) claims, a film's meaning is achieved thanks to its structure and coherence. The view of film as text corresponds to the modern approach to text as a dynamic phenomenon, which possesses features of static and verbal texts but can also be analyzed according to the context and social function (Martin and Rose 2003). The limitation of Wildfeuer and Bateman's proposals is that they have been designed for film texts only, to the exclusion of verbal texts.

Notwithstanding the fact that the current research stipulates the inclusion of adaptation (and therefore novelization) into translation studies, there still remains the question of what tools should be used to analyze the process of translation which takes place between a source text and the target text. For the purposes of her $\mathrm{Ph} . \mathrm{D}$. research, the author has adopted the framework expounded in Michał Post's book Film jako tekst multimodalny. Założenia i narzędzia jego analizy [Film as a multimodal text. Assumptions and instruments of its analysis]. The central assumptions of this interpretive framework are that (i) verbal and film texts share the same general text pattern and that (ii) film texts share the same general compositional pattern with verbal texts.

\section{Shared compositional structure of verbal and film texts}

In his research on multimodal film texts, Post looks to literary studies for details of compositional structure. Specifically, his approach to the compositional structure of film texts relates to the classical Aristotelian view of the three-part plot of verbal texts, which in further literature (Krajka and Zgorzelski) and film studies 
(Barsam and Monahan) was elaborated into variable numbers of consecutive parts, such as Prologue, Exposition, Inciting Moment, Development of Action, Climax, Denouement and Epilogue (Krajka and Zgorzelski). To cope with the lack of one accepted methodology for the delimitation of smaller compositional units of film texts, which would lend themselves to translation analyses, Post resorted to John Swales' Move and Step Theory (1990). Swales' propositions concern the composition of verbal texts, therefore they can be integrated and used in unison with the Aristotelian segments. More precisely, these segments decompose into Moves, which in turn split into Steps. Each compositional segment is a semantic unit in Wildfeuer and Bateman's sense, that is, they are the carriers of the so-called themes linked with each part and portion of the film's story. The delimited compositional segments are also multimodal chunks constituted by combinations of visual, auditory and vocal modes. Post's proposal of richly segmented compositional structure seems to be effective for estimations of degrees of modal density in texts, as each compositional segment is a multimodal chunk and may combine visual, auditory and vocal modes in varying proportions.

\section{Cognitive translation and multimodal translation}

The approach to translation that the present author found adequate and useful for her Ph.D. research on novelization was Elżbieta Tabakowska's cognitive translation, a theory of translation that relies on instruments of cognitive linguistics. Although Tabakowska has designed her framework for traditional interlingual translations, it can be extended to multimodal translations thanks to its ability to comprise the visuals and assign them roles as specific instruments of meaning analysis. Tabakowska states that the unit of translation is neither the word nor the sentence, but a bounded image or scene which verbal texts evoke in the readers' minds, the content of which can be yielded in terms of image schemas of cognitive linguistics.

The extracted units for multimodal translation are the corresponding compositional segments of multimodal (film) and monomodal texts (film's novelization), as described in the preceding section (for a detailed discussion see Post). Tabakowska (50) asserts that the process of interlingual translation is successful when both the source text and the target text use the same image schemas for the corresponding scenes or images to convey their messages. By the same token, the process of multimodal translation is successful if the corresponding scenes use the same image schemas. Whether this is the case can be estimated by comparing the corresponding scenes for their schemas. In the following section the author presents a sample of such a comparison of a film and its multimodal translation, i.e. its novelization. 
The image schemas that are applied in the comparison correlate with Kress and Van Leeuwen's (177) three principles which govern the composition of film shots and film frames, that is, salience, framing and information value, which are the main meaning-making devices. Salience is understood here as correlated with the FIGURE-GROUND perception schema. Kress and Van Leeuwen's framing links with particular parts of the film frame and screen. These zones are related to orientational image schemas, which reflect the perception and thinking processes of viewers. Kress and Van Leeuwen's zones correlate with such bipartite orientational image schemas as LEFT-RIGHT, TOP-BOTTOM, CENTREMARGIN, FRONT-BACK. As regards the information values, they are connected with particular parts of the film frame: LEFT $\rightarrow$ GIVEN and RIGHT $\rightarrow$ $\mathrm{NEW}$; TOP $\rightarrow$ IDEAL and BOTTOM $\rightarrow$ REAL; CENTRE $\rightarrow$ SALIENT and MARGINs $\rightarrow$ LESS or NON-SALIENT; FRONT $\rightarrow$ SALIENT and BACK $\rightarrow$ LESS or NON-SALIENT.

\section{A sample comparison of a movie with its multimodal translation-novelization}

The sample analysis is based on a comparison of a selected compositional segment of Christopher Nolan's film Interstellar (2014) and the corresponding part of the film's novelization by Greg Keyes (2014). The film segment and novel fragments belong to the closing part of the Denouement. There the protagonist Cooper meets his daughter after 60 years spent on his space mission. Due to the relativity of time, his daughter is biologically much older than him and she is about to die. This final part of the film lets the viewers engage emotionally in the long-awaited meeting of Cooper and his daughter Murph. Both Cooper and Murph ensure that each of them knows what really happened during the years of Cooper's space mission. For the analytical purpose, the first of the three image schema sequences of the segment are selected and juxtaposed with the related book excerpts.

\section{Image schema sequence and frame composition- a juxtaposition}

The scenes analyzed are based on dialogue rather than action, so the film frames focus mainly on the two characters just in each other's company. However, even the most minimal visual composition of a film frame conveys a lot of additional information to the viewer, which the present author has considered when contrasting the aforementioned frames with their book verbal counterparts. 


\section{Image schema sequence: The movie (running time 11 seconds)}

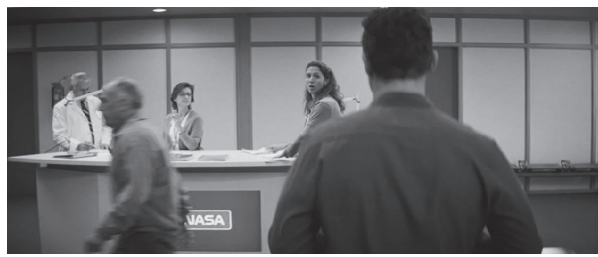

Frame 1.

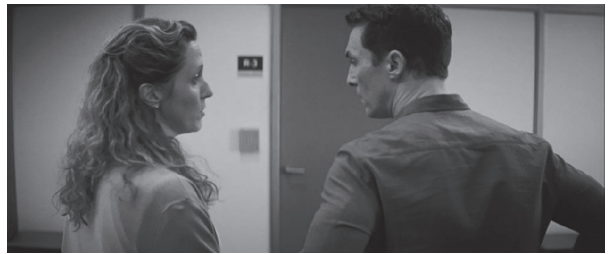

Frame 3.

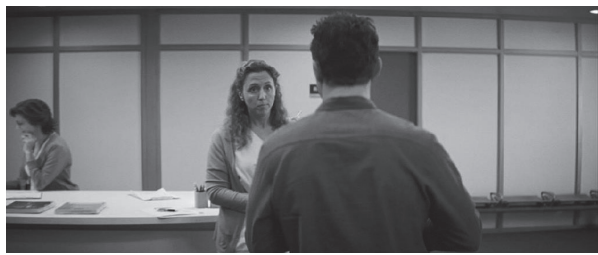

Frame 2.

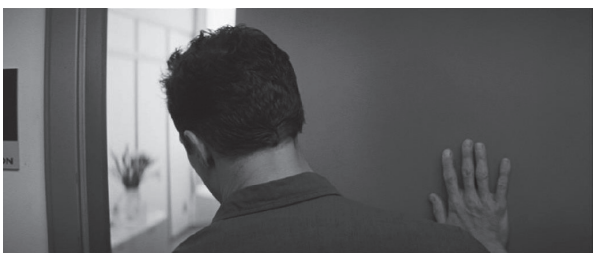

Frame 4

Figure 1.

Source: Christopher Nolan (Director). 2014. Interstellar [Motion picture]. USA: Warner Bros., Paramount Pictures.

In Frame 1 the image schemas used are the FIGURE-GROUND schema, which allows exposure of the most salient element, the LEFT-RIGHT schema and the related GIVEN-NEW schema. Cooper is the FIGURE, while the nurse and the other elements of the hospital waiting room form the GROUND. At the same time, the LEFT $\rightarrow$ GIVEN and RIGHT $\rightarrow$ NEW schemas are employed. The hospital reception is on the LEFT as something obvious and of less importance than the RIGHT part of the frame, which shows the nurse and Cooper as the new and key elements in this frame. The FRONT (Cooper)-BACK (the nurse) image schema completes the description of Frame 1.

Frame 2 shows Cooper as the FIGURE and NEW $\rightarrow$ RIGHT of the image schemas, while the nurse is the GROUND and GIVEN $\rightarrow$ LEFT of the same image schemas, as the viewer sees the nurse on the LEFT side of the frame and Cooper on the RIGHT side of it. The analysis of Frame 2 is completed by the FRONT (Cooper)-BACK (the nurse) image schema. Frame 3 shows Cooper and the nurse together as the FIGURE of this part of the movie, simultaneously assigning to them the GIVEN (the nurse)-NEW (Cooper) information values. The CENTRE, but of the GROUND, is represented by the door. In Frame 4 the viewer sees Cooper and the upper part of the door which he is opening with his hand. The Frame shows Cooper's head as the FRONT, while the door occupies the RIGHTmost part of the frame, therefore NEW is the information value attached to it. On the LEFT, the opening door slowly reveals the sight of the windows in the room (GIVEN) that Cooper 
is entering. Frame 4 shows what Kress and Van Leeuven described as a change of information value. The GIVEN-NEW image schema reflects the fact that the room Cooper is entering becomes the NEW element in this frame, while the NEW information value associated with Cooper all through the Image Schema Sequence 1 changes to GIVEN. The change of information value is evidenced by the first frame of Image Schema Sequence 2, in which the viewers see Cooper on the LEFT $\rightarrow$ GIVEN of the frame, while the room and the family in the background of it cover the space from the CENTRE to the RIGHT $\rightarrow$ NEW. ${ }^{1}$

\section{Image schema sequence 1: The novelization}

The book counterpart presents the same scene as follows:

A nurse was waiting for Cooper as he nervously entered the hospital waiting room.

"Is she ...?" he left it hanging in a way not sure what the question really was.

"The family is all in here," the nurse told him.

"The family?" he asked.

"They all came to see her," she replied. "She's been in cryosleep for almost two years."

She indicated the door and taking a deep breath Cooper erased it open. (Keys 274)

In the quoted excerpt, only in its first line is the nurse the FIGURE, while Cooper and the hospital waiting room belong to the GROUND part of the image schema. The rest of the excerpt advocates Cooper's perspective as dominant by assigning to him the FIGURE information value of the FIGURE-GROUND image schema. Beyond the first line of the excerpt, it is only the nurse who is the explicit part of the GROUND. The reader does not get any other information about the place Cooper is in, contrary to the film where the viewer can see the details of the interior of the waiting room. Apparently, the GROUND of the excerpt is devoid of such details in comparison with the film. However, it should be noted that the first line of the text most probably activates the reader's world knowledge about hospitals which may provide the required elements of the hospital waiting room GROUND. The present author suggests that the GROUND is explicitly represented by the nurse and implicitly by the activated parts of the reader's world knowledge.

In the excerpt, the NEW-GIVEN image schema has been applied in the manner described by Kress and Van Leeuwen, that is, the NEW information becomes GIVEN information. For example Is she... has the value NEW, also the nurse's answer The family is all here is NEW, in Coopers question The family? is also NEW. But the nurses answer They all came to see her is already GIVEN, while She's been in cryosleep for almost two years is again NEW. The film and the book apply the same GIVEN-NEW image schema in ways appropriate to their

${ }^{1}$ Kress and Van Leeuwen (185) observed that sequences of sentences in a multi-sentence text are regularly based on the pattern NEW becomes GIVEN, characteristic of language both in speech and writing. 
modalities: visual modality in the movie and verbal modality in the excerpt. Special attention should be paid to the metaphorical use of the verb erase, which in the book describes the way of opening the door by Cooper. The present author suggests that the understanding of the verb erase is determined by the conceptual metaphor Opening Doors Is the Removal of Last Barriers, with the barriers between Cooper and his daughter finally disappearing. In the film, none of its modalities evoke this metaphor-Cooper literally opens the door with his hand.

The above is not a complete multimodal translation analysis as it focuses on the visual mode only. What has been excluded is the enumeration of cognitive schemas underlying dialogues (vocal mode) and music (auditory mode), which render certain other aspects of the novelization. One of the modalities may dominate, like the dialogues in the sample, but the three are always present, jointly forming meanings and messages. However, a complete multimodal translation analysis was not the goal in this part of the present paper. The author intended to show that Tabakowska's translation framework can be applied to multimodal texts as well.

\section{Conclusions}

The current theory of dynamic adaptation networks requires that multimodal film texts be necessarily viewed as linked (i) with their monomodal verbal sources (traditional film adaptations), or (ii) with their monomodal verbal outputs (traditional film novelizations). The present author adhered to the view that the interplay of multimodal film texts with monomodal novelization texts is an instance of specific translation. Such a conclusion immediately brings to mind Jakobson's idea of intersemiotic translation as a possible approach to take. But this scholar's proposal is only a stimulating postulate which requires a detailed elaboration, before it becomes operational (Hopfinger). Hopefully, the sample analysis showed that the extension of Tabakowska's cognitive translation theory to multimodal texts (movies in this case) makes it an adequate analytical framework for an orderly and systematic comparison of the film with its novelization.

Tabakowska's translation theory uses cognitive instruments for traditional interlingual translations, i.e. translations of monolingual verbal texts. The interaction of cognitive instruments with linguistic structures is an empirical fact, as has been amply evidenced by cognitive linguistics research. Also, the crucial role of the cognitive instrument of conceptual metaphor in visual narrations has been demonstrated by numerous analyses of comics (the newest one is Szawerna). Earlier, both Chattah and Ward argued convincingly that cognitive instruments are also involved in sound and music organization. In view of these facts, it was logical, and even necessary, for the author to hypothesize that cognitive instruments also operate in films, which combine moving pictures with language and sound and music. The presented sample analysis showed the privileged role and the indispensability of 
orientational image schemata: CENTRE-PERIPHERY, FRONT-BACK and the like (see also Johnson on the role of such schemas in films). Viewing novelization as an example of multimodal translation opens the door to a new area of translation research, in which constructs and methods of cognitive linguistics can be effectively applied to comparisons of texts based on verbal and non-verbal modalities. On a more general plane, the same research can contribute both to translation studies and multimodal text semantics.

\section{References}

Baetens, J. 2005. "Novelization, a Contaminated Genre?" Critical Inquiry 32.1. 43-60.

- 2010. "Expanding the Field of Constraint: Novelization as an Example of Multiple Constrained Writing." Poetics Today 31.1 51- 79.

Barsam, R. M., and D. Monahan. 2010. Looking at Movies: An Introduction to Film. New York: W.W. Norton and Company.

Bateman, J. A. 2014. Text and Image: A Critical Introduction to the Visual/Verbal Divide. Abingdon: Routledge.

Bateman, J., and K.-H. Schmidt. 2012. Multimodal Film Analysis: How Films Mean. New York: Routledge.

Cahir, L. C. 2006. Literature into Film: Theory and Practical Approaches. Jefferson: McFarland and Co.

Cardwell, S. 2002. Adaptation Revisited: Television and the Classic Novel. Manchester: Manchester UP.

Chattah, J. 2015. “Film Music Embodiment.” In: Coegnarts, M., and P. Kravanja (eds.). Embodied Cognition and Cinema. Leuven: Leuven UP, 81- 112.

Coegnarts, M., and P. Kravanja (eds.). 2015. Embodied Cognition and Cinema. Leuven: Leuven UP. Dusi, N. 2015. "Intersemiotic Translation: Theories, Problems, Analysis." Semiotica 206. 181-215. Eco, U. 2008. Experiences in Translation. Toronto: U of Toronto P.

Gottlieb, H. 2005. "Multidimensional Translation: Semantics turned Semiotics." Challenges of Mulitidimentional Translation: Conference Proceedings. https://www.euroconferences.info/proceedings/2005_Proceedings/2005_Gottlieb_Henrik.pdf.

Halliday, M. A. K., and R. Hassan. 1976. Cohesion in English. London: Longman.

Hendrykowski, M. 2013. “Adaptacja jako przekład intersemiotyczny.” Przestrzenie teorii 20. 175184.

Hopfinger, M. 1974. Adaptacje filmowe utworów literackich: problemy teorii i interpretacji. Wrocław: Zakład Narodowy im. Ossolińskich.

Hutcheon, L. 2006. A Theory of Adaptation. London: Routledge.

Jakobson, R. 1959. “On Linguistic Aspects of Translation.” In: Brower, R. A. (ed.). On Translation. Cambridge, MA: Harvard UP, 232-239.

Johnson, M. 2015. "Foreword." In: Coegnarts, M., and P. Kravanja (eds.). Embodied Cognition and Cinema. Leuven: Leuven UP, 9 - 13.

Keyes, G. 2014. Interstellar: The Official Movie Novelization. London: Titan Books.

Krajka, W., and A. Zgorzelski. 1984. On the Analysis of the Literary Text. Warszawa: Państwowy Instytut Wydawniczy.

Kress, G. R., and T. Van Leeuwen. 2006. Reading Images: The Grammar of Virtual Design. London: Routledge. 
Larsson, R. 1995. Films into Books: An Analytical Bibliography of Film, Novelization, Movie and Tie-Ins. London: Scarecrow Press.

Martin, J. R., and D. Rose. 2003. Working with Discourse: Meaning Beyond the Clause. London: Bloomsbury Academic.

Murphy, A. L. 2013. "Reverse Adaptation and Continuing Engagement in Transmedia Storytelling." In: Harper, G. (ed.). New Ideas in Writing Arts. Newcastle upon Tyne: Cambridge Scholars Publishing, 17-32.

Newell, K. 2017. Expanding Adaptation Networks: From Illustration to Novelization. London: Palgrave Macmillan UK.

Polakowski, J. 1982. "Metoda przekładu intersemiotycznego w kształceniu sprawności językowej." Oświata $i$ wychowanie 17. 18-21.

Post, M. 2017. Film jako tekst multimodalny. Założenia i narzędzia jego analizy. Wrocław: Wydawnictwo Wyższej Szkoły Filologicznej.

Stam, R. 2005. "Introduction: The Theory and Practice of Adaptation." In: Stam, R., and A. Raengo (eds.). Literature and Film: A Guide to the Theory and Practice of Film Adaptation. Oxford: Blackwell Publishing, 1-52.

Swales, J. 1990. Genre Analysis: English in Academic and Research Settings. Cambridge: Cambridge UP.

Szawerna, M. 2017. Metaphoricity of Conventionalized Diegetic Images in Comics: A Study in Multimodal Cognitive Linguistics. Frankfurt am Main: Peter Lang.

Tabakowska, E. 2001. Językoznawstwo kognitywne a poetyka przekładu. Kraków: Universitas.

Thomas E., Nolan Ch., Obst L. (Producers) and Nolan, Ch. (Director). 2014. Interstellar [Motion picture]. USA: Warner Bros., Paramount Pictures.

Tomaszkiewicz, T. 2006. Przektad audiowizualny. Warszawa: Wydawnictwo Naukowe PWN.

Van Parys, T. 2009. "The Commercial Novelization: Research, History, Differentiation." Literature/ Film Quarterly 37.4 305-17.

—. 2011. "The Study of Novelization: A Typology and Secondary Bibliography." Belphégor X.2 (August). https://dalspace.library.dal.ca/bitstream/handle/10222/53191/10_02_paryst_noveli_ en cont.pdf? sequence $=1 \&$ isAllowed $=y$.

Ward, M. S. 2015. "Art in Noise: An Embodied Simulation Account of Cinematic Sound Design." In: Coegnarts, M., and P. Kravanja (eds.). Embodied Cognition and Cinema. Leuven: Leuven UP, $155-186$.

Wildfeuer, J. 2014. Film Discourse Interpretation: Towards A New Paradigm for Multimodal Film Analysis. New York: Routledge.

Wildfeuer, J., and J. A. Bateman (eds.). 2017. Film Text Analysis: New Perspectives On The Analysis Of Filmic Meaning. New York: Routledge. 